\title{
Synthesis and Hydrolysis of Malyl-Coenzyme A by Pseudomonas AM 1: an Apparent Malate Synthase Activity
}

\author{
By R. B. COX AND J. R. QUAYLE \\ Department of Microbiology, The University, Sheffield SIO $2 T N$
}

(Received 5 December 1975)

\begin{abstract}
SUMMARY
The malate synthase activity detectable in crude extracts of Pseudomonas AMI has been shown to be due to a coupling of a malyl-CoA hydrolase with malyl-CoA lyase and not due to a discrete malate synthase enzyme. The partial purification of this malyl-CoA hydrolase from Pseudomonas AMI has shown that it is distinct from citrate synthase which also hydrolyses malyl-CoA. The malyl-CoA hydrolase has a low $K_{\mathrm{m}}$ for malyl-CoA $\left(7^{\circ} 0 \mu \mathrm{M}\right)$. A mutant of Pseudomonas AMI, ICT5I (Taylor \& Anthony, 1975), which is unable to grow on ethanol, malonate or 3-hydroxybutyrate, has been shown to have an altered malyl-CoA hydrolase with a $K_{\mathrm{m}}$ for malyl-CoA 30 times higher than that of the enzyme present in the wildtype organism. Two classes of revertants to growth on these substrates have been isolated: (i) those with a malyl-CoA hydrolase of similar $K_{\mathrm{m}}$ to the wild-type and (ii) those in which the malyl-CoA hydrolase activity remains the same as in the mutant ICT5I. The nature of the mutation leading to the latter class of revertants is unknown.
\end{abstract}

\section{INTRODUCTION}

Malate synthase activity (measured as the glyoxylate-dependent cleavage of the acylCoA bond in acetyl-CoA as in equation 3, below) has been reported in Pseudomonas AMI at specific activities between 10 and 40 munits/mg protein in crude extracts of the organism grown on $\mathrm{C}_{1}, \mathrm{C}_{2}, \mathrm{C}_{3}$ and $\mathrm{C}_{4}$ compounds (Large \& Quayle, 1963; Dunstan, Anthony \& Drabble, 1972; Dunstan \& Anthony, 1973; Salem, Hacking \& Quayle, 1973a, b; Salem et al., 1973c). A 'malate synthase pathway' has been proposed (see Anthony, 1975) as the route for carbon assimilation during the growth of Pseudomonas AMI on ethanol, on malonate and on 3-hydroxybutyrate. This pathway is similar to the glyoxylate cycle (Kornberg, 1959), except in the way in which acetyl-CoA is converted to glyoxylate; Pseudomonas AMI does not synthesize detectable amounts of isocitrate lyase under any growth conditions yet tested (Large \& Quayle, 1963; Dunstan et al., 1972) and the mechanism of this oxidation of acetate to glyoxylate is not known. Salem et al. (I973b) have pointed out that the malate synthase activity measured in crude extracts of Pseudomonas AM I might be due to a coupling of malyl-CoA lyase which catalyses the reversible reaction (equation I) (Hacking \& Quayle, 1974) with a malyl-CoA hydrolase (equation 2) or acyl-CoA transferase, e.g.

$$
\begin{gathered}
\text { Acetyl-CoA }+ \text { glyoxylate } \rightleftharpoons \text { malyl-CoA } \\
\text { Malyl-CoA }+\mathrm{H}_{2} \mathrm{O} \longrightarrow \text { malate }+\mathrm{CoASH} \\
\hline \text { Sum: } \quad \text { Acetyl-CoA }+ \text { glyoxylate }+\mathrm{H}_{2} \mathrm{O} \longrightarrow \text { malate }+\mathrm{CoASH}
\end{gathered}
$$

Attempts to purify malate synthase from Pseudomonas AMI by ammonium sulphate precipitation and ion-exchange chromatography have led only to an enrichment of malyl-CoA lyase activity (Quayle \& Hancock, unpublished observations). However, a malate synthase 
enzyme has been completely separated from malyl-CoA lyase in trimethylamine-grown bacterium $5 \mathrm{H} 2$ by $\mathrm{Cox}$ (1974); this is a facultative methylotroph which uses the isocitrate lyase-serine pathway for growth on $\mathrm{C}_{1}$ compounds (Hampton \& Zatman, 1973; Cox \& Zatman, 1973). The molecular weights of malate synthase and malyl-CoA lyase in this organism were approximately 90000 and 290000 respectively and separation was achieved by gel-filtration on Sephadex G-200. This demonstration of a malate synthase in bacterium 5H2 suggested that it might be possible to determine, by gel-filtration, whether or not there is a similar enzyme present in Pseudomonas AMI. This paper reports the results of such an investigation in which a new enzyme catalysing the hydrolysis of malyl-CoA has been found.

\section{METHODS}

Chemicals. Coenzyme A, oxaloacetic acid, 5,5'-dithiobis-(2-nitrobenzoate) (DTNB), catalase (EC. I.II.I.6) (from beef liver), lactate dehydrogenase (EC. I.I.I.27) (from rabbit muscle) and citrate synthase (EC. 4.I.3.7) (from pig heart) were obtained from Boehringer Corporation (London) Ltd, Lewes, East Sussex. Phenylhydrazine- $\mathrm{HCl}$, glyoxylic acid and cytochrome $c$, type III (from horse heart) were from Sigma. Apoferritin was a gift from Dr Pauline M. Harrison, University of Sheffield. (2S)-4-Malyl-CoA, (2R)-4-malylCoA, acetyl-CoA and succinyl-CoA were prepared as described by Hacking \& Quayle (1974); (RS)-3-hydroxybutyryl-CoA was prepared from $\beta$-butyrolactone (K \& K Fine Chemicals, supplied by Kodak Ltd, Kirkby, Liverpool) and CoA by the method of Decker (1963) at $0^{\circ} \mathrm{C}$ in $0.5 \mathrm{M}-\mathrm{KHCO}_{3}, \mathrm{pH} \mathrm{8.5}$. Acetyl-CoA was assayed enzymically using citrate synthase and excess oxaloacetate, and measuring the formation of free CoA with DTNB (Tubbs \& Garland, 1969). Other CoA esters were assayed enzymically using malylCoA hydrolase prepared from succinate-grown Pseudomonas AmI (see Results) or by hydrolysis in $0.1 \mathrm{M}-\mathrm{NaOH}$ at $30{ }^{\circ} \mathrm{C}$ for $10 \mathrm{~min}$, followed by neutralization and measurement of free CoA with DTNB.

DEAE-cellulose (pre-swollen DE-52) was obtained from Whatman Biochemicals, and Sephadex G-200 from Pharmacia.

Maintenance and growth of organisms. The mineral medium of Jayasuriya (1955) supplemented with growth substrates at a concentration of $0.2 \%$ was used as the growth medium. It was solidified for the preparation of agar slopes and plates by adding $I \cdot 5 \%(\mathrm{w} / \mathrm{v})$ Difco Bacto-agar. Pseudomonas AM I (NCIB9I33) was maintained on agar slopes containing methylamine hydrochloride. The organism was subcultured monthly and stored at $4{ }^{\circ} \mathrm{C}$ after incubation for 3 to 4 days at $30^{\circ} \mathrm{C}$.

The following mutants of Pseudomonas AM I were generously supplied by Dr C. Anthony and Mr I. J. Taylor, University of Southampton: PCT57, ICT5I and ICT5IR. PCT57R4 was isolated in this department by Salem, Hacking \& Quayle (1974). PCT57, ICT5I and ICT5IR were maintained on succinate-agar slopes and PCT57R4 was maintained on methylamineagar slopes. Revertants of ICT5I isolated in this work, ICT5IRaI, a2, bI, b2 and cI, were maintained on hydroxybutyrate-agar slopes containing streptomycin ( $\mathrm{I} \mathrm{mg} \mathrm{ml}^{-1}$ ).

For the preparation of crude extracts, cultures (I l) were grown in 21 conical flasks incubated at $30^{\circ} \mathrm{C}$ on an orbital shaker (200 rev./min). The growth of liquid cultures was followed spectrophotometrically at $650 \mathrm{~nm}$ using a Pye Unicam SP60o spectrophotometer; readings were referred to an $E_{650}$-dry weight calibration curve for succinate-grown Pseudomonas AMI.

Isolation of revertants of ICT5I. Streptomycin resistant $\left(\mathrm{Sm}^{\mathrm{r}}\right)$ strains of ICT5 I were prepared prior to isolation of revertants. ICT5 I was grown in liquid succinate medium and 
approximately $\mathrm{IO}^{8}$ bacteria were spread on succinate-agar plates containing streptomycin ( $\mathrm{I} \mathrm{mg} \mathrm{ml}^{-1}$ ). After incubation at $30^{\circ} \mathrm{C}$ for 7 days, several $\mathrm{Sm}^{\mathrm{r}}$ colonies were picked off and streaked out on streptomycin-succinate-agar plates. Three of these $\mathrm{Sm}^{\mathrm{r}}$ strains, designated ICT $5 \mathrm{I}$ a, $\mathrm{b}$ and $\mathrm{c}$, which retained the growth characteristics of the original mutant, were grown in liquid succinate medium and approximately $10^{8}$ bacteria plated out on hydroxybutyrateagar plates containing streptomycin (I $\mathrm{mg} \mathrm{ml}^{-1}$ ). Several spontaneous revertants were isolated from each ICT5I Sm${ }^{\mathrm{r}}$ strain and five of them, designated ICT5IRaI, a2, bI, b2 and cI (from the three $\mathrm{Sm}^{\mathrm{r}}$ strains) were streaked out and used in the experiments described.

Preparation of crude extracts. Cultures of organisms for the preparation of crude (bacteriafree) extracts were harvested in mid-exponential phase and washed once in ice-cold $0.02 \mathrm{M}$ $\mathrm{KH}_{2} \mathrm{PO}_{4}-\mathrm{KOH}$ buffer $\mathrm{pH} 7 \cdot 0$. Pellets were either stored at $-15^{\circ} \mathrm{C}$ or used immediately for the preparation of crude extracts. Thick suspensions of organisms in this phosphate buffer were disrupted by passing once through a French pressure cell (American Instrument Co., Silver Spring, Maryland, U.S.A.), pre-cooled to $0^{\circ} \mathrm{C}$, at a pressure of $15000 \mathrm{lbf} \mathrm{in}^{-2}$ (I03 $\mathrm{MPa}$ ); whole organisms and debris were removed by centrifuging at $35000 \mathrm{~g}$ for $30 \mathrm{~min}$ at $4{ }^{\circ} \mathrm{C}$. For one experiment (see text) organisms were washed and the extract prepared in $0.02 \mathrm{M}-$ Tris- $\mathrm{HCl}$ buffer, $\mathrm{pH} \mathrm{8.0,} \mathrm{containing} \mathrm{0.0I} \mathrm{M}-\mathrm{MgCl}_{2}$.

Protein determination. Protein was measured with the Folin phenol reagent by the method of Kennedy \& Fewson (1968), using crystalline bovine plasma albumin as the standard.

Enzyme assays. All enzyme assays were done at $30^{\circ} \mathrm{C}$ using a Pye Unicam SPI80o double-beam recording spectrophotometer.

Citrate synthase [citrate oxaloacetate-lyase (CoA-acetylating), EC. 4.1.3.7] was assayed at $\mathrm{pH} 8.0$ by the method of Srere (1969).

Malyl-CoA lyase [malyl-CoA glyoxylate-lyase, EC. 4. I . 3.24] was assayed by the method of Salem et al. (1973b) but was detected in fractions of eluates from DEAE-cellulose and Sephadex G-20o columns using a lower concentration ( $40 \mu \mathrm{M})$ of malyl-CoA.

Malate synthase [L-malate glyoxylate-lyase (CoA-acetylating), EC. 4.I.3.2] was assayed by the method of Dixon \& Kornberg (1962). This activity was also assayed using a modification of the method in which the formation of free CoA was followed spectrophotometrically at $4 \mathrm{I} 2 \mathrm{~nm}$ by including DTNB $(0.2 \mathrm{mM})$ in the reaction mixture.

Malyl-CoA hydrolase was routinely assayed in a reaction mixture (total volume, $\mathrm{I} \mathrm{ml}$ ) containing I00 $\mu \mathrm{mol}$ Tris-HCl buffer, $\mathrm{pH} 8 \cdot 0 ; 50 \mu \mathrm{mol} \mathrm{MgCl}_{2} ; 0.2 \mu \mathrm{mol}$ DTNB; $0.04 \mu \mathrm{mol}$ $(2 S)-4$-malyl-CoA. (The DTNB was prepared as a $2 \mathrm{mM}$ solution in $0.02 \mathrm{M}-\mathrm{KH}_{2} \mathrm{PO}_{4}-\mathrm{KOH}$ buffer, $\mathrm{pH} 77^{\circ}$.) Reactions were started by the addition of enzyme or malyl-CoA and followed spectrophotometrically at 4I $2 \mathrm{~nm}$. Mixtures lacking malyl-CoA or in which boiled extract was substituted for crude extract were used as controls. Specific activities were calculated assuming that $\epsilon_{412}$ for the mercaptide ion was $13.6 \times 10^{-3} \mathrm{M}^{-1} \mathrm{~cm}^{-1}$ (Srere, I969).

Enzyme units. One enzyme unit is the amount of enzyme that catalyses the transformation of I $\mu \mathrm{mol}$ of substrate/min (or the formation of I $\mu \mathrm{mol}$ of product $/ \mathrm{min}$ ) at $30^{\circ} \mathrm{C}$ under the assay conditions described.

Phosphate determination. Inorganic phosphate concentrations were determined using the Fiske \& SubbaRow procedure (Leloir \& Cardini, 1957).

Determination of $K_{\mathrm{m}}$ values. $K_{\mathrm{m}}$ values were determined by double reciprocal plots (Lineweaver \& Burk, I934). 
Table I. Specific activities of malyl-CoA hydrolase, malyl-CoA lyase, citrate synthase and 'malate synthase' in crude extracts of Pseudomonas AMI and mutants

Enzymes were assayed as described in Methods; malyl-CoA hydrolase was assayed using $40 \mu \mathrm{M}$-malyl-CoA.

\begin{tabular}{|c|c|c|c|c|c|c|}
\hline \multirow[b]{2}{*}{ Organism } & \multirow[b]{2}{*}{$\begin{array}{l}\text { Growth } \\
\text { substrate }\end{array}$} & \multirow[b]{2}{*}{$\begin{array}{l}\text { Mean } \\
\text { doubling } \\
\text { time (h) }\end{array}$} & \multicolumn{4}{|c|}{ Specific activities (munits/mg protein) } \\
\hline & & & $\begin{array}{l}\text { Malyl-CoA } \\
\text { hydrolase }\end{array}$ & $\begin{array}{c}\text { Malyl-CoA } \\
\text { lyase }\end{array}$ & $\begin{array}{l}\text { Citrate } \\
\text { synthase }\end{array}$ & $\begin{array}{l}\text { 'Malate } \\
\text { synthase' }\end{array}$ \\
\hline $\begin{array}{l}\text { Pseudomonas AM I } \\
\text { wild-type }\end{array}$ & $\begin{array}{l}\text { Methanol } \\
\text { Hydroxybutyrate } \\
\text { Succinate }\end{array}$ & $\begin{array}{l}3 \cdot 5 \\
6 \cdot 9 \\
3 \cdot 5\end{array}$ & $\begin{array}{l}45 \\
70 \\
56\end{array}$ & $\begin{array}{r}718 \\
93 \\
200\end{array}$ & $\begin{array}{r}55 \\
108 \\
156\end{array}$ & $\begin{array}{l}28 \\
19 \\
40\end{array}$ \\
\hline ICT5I & $\begin{array}{l}\text { Methanol } \\
\text { Succinate }\end{array}$ & $\begin{array}{l}4 \cdot 0 \\
4 \cdot 5\end{array}$ & $\begin{array}{r}5 \\
14\end{array}$ & $\begin{array}{l}840 \\
195\end{array}$ & $\begin{array}{r}75 \\
181\end{array}$ & $\begin{array}{l}\text { ND } \\
\text { ND }\end{array}$ \\
\hline ICT5IR & $\begin{array}{l}\text { Hydroxybutyrate } \\
\text { Succinate }\end{array}$ & $\begin{array}{l}9 \cdot 7 \\
3 \cdot 5\end{array}$ & $\begin{array}{r}7 \\
14\end{array}$ & $\begin{array}{l}112 \\
165\end{array}$ & $\begin{array}{r}42 \\
168\end{array}$ & $\begin{array}{l}\text { ND } \\
\text { ND }\end{array}$ \\
\hline ICT5IRaI & Hydroxybutyrate & $14 \cdot 5$ & I I & 270 & $7 \mathrm{I}$ & ND \\
\hline ICT5IRa2 & Hydroxybutyrate & $9 \cdot 2$ & 74 & 80 & IOI & 35 \\
\hline ICT5IRbI & Hydroxyburtyate & $8 \cdot 8$ & $5 \mathrm{I}$ & 74 & 123 & 25 \\
\hline ICT5IRb2 & Hydroxybutyrate & $10 \cdot 6$ & II & 84 & II3 & ND \\
\hline ICT5IRCI & Hydroxybutyrate & $7 \cdot 8$ & 63 & 74 & 153 & 27 \\
\hline PCT57 & Hydroxybutyrate & $5 \cdot 5$ & 76 & 4 & 107 & ND \\
\hline PCT57R4 & Methanol & 5.9 & 43 & 730 & 75 & 38 \\
\hline
\end{tabular}

\section{RESULTS}

\section{Chromatography of crude extract on Sephadex G-200}

An experiment similar to that described by Cox (1974) was performed in an attempt to resolve whether or not the malate synthase activity observed in crude extracts of Pseudomonas AMI (Table I) was due to the presence of a malate synthase enzyme. A crude extract $(20 \mathrm{mg}$ protein $\mathrm{ml}^{-1}$ ) of succinate-grown Pseudomonas AMI was prepared in $0.02 \mathrm{M}$-Tris- $\mathrm{HCl}$ buffer, $\mathrm{pH} 8 \cdot 0$, containing $0.0 \mathrm{I} \mathrm{M}-\mathrm{MgCl}_{2}$. Nucleic acids were removed at $0^{\circ} \mathrm{C}$ by the dropwise addition of a solution of protamine sulphate ( $10 \mathrm{mg} \mathrm{ml}^{-1}$ in the same Tris buffer) to a final concentration of $0.1 \mathrm{mg}$ protamine sulphate per $\mathrm{mg}$ protein, followed by centrifuging (20000 $\mathrm{g}$; I0 $\mathrm{min}$ ). The supernatant (I $20 \mathrm{mg}$ protein; $8 \mathrm{ml}$ ) was applied to a Sephadex G-200 column $(85 \times 2.5 \mathrm{~cm})$ equilibrated at $4{ }^{\circ} \mathrm{C}$ with $0.02 \mathrm{M}-\mathrm{Tris}-\mathrm{HCl}$ buffer, $\mathrm{pH} 8 \cdot 0$, containing $0.01 \mathrm{M}-\mathrm{MgCl}_{2}$. The column was eluted with this buffer and fractions $(4.5 \mathrm{ml})$ were assayed for malate synthase, malyl-CoA lyase, malyl-CoA hydrolase and citrate synthase activities.

Apparent malate synthase activity (total $7 \cdot 2$ units) was detected in fractions 33 to 45 with maximum activity between fractions 38 and 40 . No other peak of malate synthase activity was detected. However, coincident with this activity were peaks of malyl-CoA lyase activity (total 10.3 units) and a malyl-CoA hydrolase activity (total 7.4 units), both measured using $40 \mu \mathrm{M}$-malyl-CoA. Citrate synthase was also present (total $\mathrm{I} 2.6$ units) but the peak of this activity lay between fractions 35 and 37 . Thus the malate synthase activity detected in the eluate could have been due to a coupling of the malyl-CoA lyase and malyl-CoA hydrolase activities. The peak of this latter activity did not coincide with that of citrate synthase, indicating that the hydrolase activity was not due to citrate synthase, which is known to hydrolyse malyl-CoA (Eggerer, Remberger \& Grünewälder, 1964). Fractions 36 to 42 were 


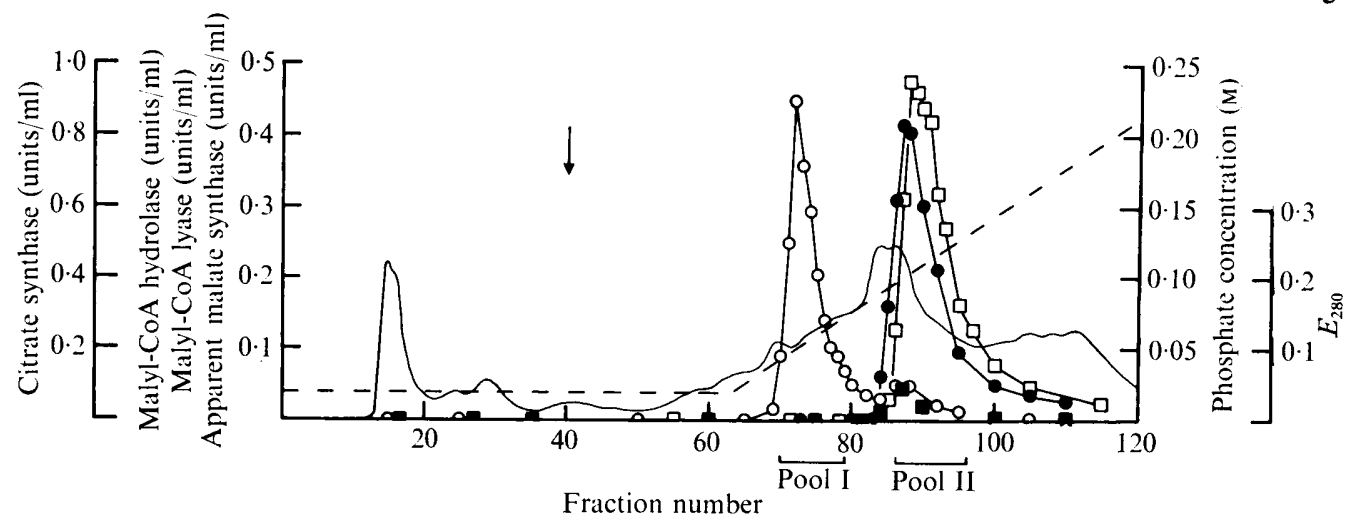

Fig. I. DEAE-cellulose chromatography of a crude extract of succinate-grown Pseudomonas AMI. Malyl-CoA hydrolase $(O)$ and malyl-CoA lyase $(\square)$ were assayed with $40 \mu \mathrm{M}$-malyl-CoA. Citrate synthase (O), and apparent malate synthase activity $(\square)$ were assayed as described in Methods. $\longrightarrow, E_{280}$ of the column eluate, measured with a Uvicord u.v. monitor (light path $3 \mathrm{~mm}$ ). --- , Phosphate concentration; the arrow shows where the phosphate gradient was started.

pooled and attempts were made to separate any malate synthase activity present from the malyl-CoA lyase and malyl-CoA hydrolase activities by fractionation with increasing concentrations of $\left(\mathrm{NH}_{4}\right)_{2} \mathrm{SO}_{4}$ and also by chromatography on DEAE-cellulose, but without success. Both malyl-CoA lyase and malyl-CoA hydrolase were always present in those fractions which contained apparent malate synthase activity and at no time was more malate synthase activity detected than could be accounted for by the lyase and hydrolase acting together. Crude extracts of Pseudomonas AMI were then fractionated (see below) to separate the malyl-CoA hydrolase activity from malyl-CoA lyase and to characterize the former.

\section{Chromatography of crude extract on DEAE-cellulose}

A crude extract ( $33 \mathrm{mg}$ protein $\mathrm{ml}^{-1}$ ) of succinate-grown Pseudomonas AMI was prepared in $0.02 \mathrm{M}-\mathrm{KH}_{2} \mathrm{PO}_{4}-\mathrm{KOH}$ buffer, $\mathrm{pH} 7 \cdot 0$, and nucleic acids were removed by the addition of a protamine sulphate solution ( $10 \mathrm{mg} \mathrm{ml}^{-1}$ ) in this phosphate buffer to a final concentration of $0.1 \mathrm{mg}$ protamine sulphate per $\mathrm{mg}$ protein. The supernatant (I $30 \mathrm{mg}$ protein; $7.7 \mathrm{ml}$ )

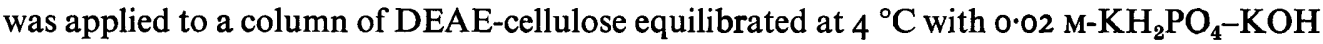
buffer, $\mathrm{pH} 7 \cdot 0$, and the column was eluted with approx. $\mathrm{I} 80 \mathrm{ml}$ of this buffer and then with a linear gradient of 0.02 to $0.5 \mathrm{M}-\mathrm{KH}_{2} \mathrm{PO}_{4}-\mathrm{KOH}$ buffer, $\mathrm{pH} 7.0$ (500 ml total) (Hacking \& Quayle, 1974). Fractions $(4.5 \mathrm{ml})$ were collected and assayed for malyl-CoA hydrolase, malyl-CoA lyase, malate synthase and citrate synthase (Fig. I). After individual fractions had been assayed for these enzyme activities and phosphate concentrations determined, fractions 70 to 78 and fractions 86 to 95 were combined to give two pools, I and II, respectively; these pools (approx. $40 \mathrm{ml}$ each) were concentrated to volumes of $3.9 \mathrm{ml}$ and $3.2 \mathrm{ml}$ respectively, by filtering under pressure (nitrogen gas at $30 \mathrm{lbf}^{-2} ; 0.2 \mathrm{MPa}$ ) through a PMro ultrafiltration membrane (Amicon Ltd, High Wycombe, Buckinghamshire). Pool I concentrate contained 8.9 units of malyl-CoA hydrolase; no malate synthase, citrate synthase or malyl-CoA lyase activities were detectable. Pool II concentrate contained 27.3 units of malyl-CoA lyase (measured with $200 \mu \mathrm{M}$-malyl-CoA), 24.7 units of citrate synthase, but only $\mathrm{I} \cdot 2$ units of apparent malate synthase activity. The malyl-CoA hydrolase activity in this pool ( $\mathrm{I} \cdot 4$ units, measured with $40 \mu \mathrm{M}-$ malyl-CoA) was probably due in part to contamination by the hydrolase activity eluted earlier from the column (Fig. I); but the 
Table 2. $K_{\mathrm{m}}$ values for malyl-CoA: hydrolysis catalysed by crude extracts and partially purified preparations of Pseudomonas AM I and mutants

Reaction mixtures (I ml) contained: $100 \mu \mathrm{mol}$ Tris- $\mathrm{HCl}$ buffer, $\mathrm{pH} 8 \cdot 0$; $50 \mu \mathrm{mol} \mathrm{MgCl}_{2}$ (omitted from determinations using citrate synthase preparations); $0.2 \mu \mathrm{mol}$ DTNB; and one of a range of concentrations of malyl-CoA. Reactions were started by the addition of crude extract or enzyme preparation and the rate of hydrolysis at $30{ }^{\circ} \mathrm{C}$ was followed at $412 \mathrm{~nm}$.

\begin{tabular}{|c|c|c|c|c|}
\hline \multirow[b]{3}{*}{ Organism } & \multirow[b]{3}{*}{$\begin{array}{l}\text { Growth } \\
\text { substrate }\end{array}$} & \multicolumn{3}{|c|}{$K_{\mathrm{m}}$ values $(\mu \mathrm{M})$} \\
\hline & & \multirow[b]{2}{*}{$\begin{array}{l}\text { Crude } \\
\text { extract }\end{array}$} & \multicolumn{2}{|c|}{ DEAE-cellulose column eluate } \\
\hline & & & $\begin{array}{c}\text { Peak I } \\
\text { (malyl-CoA hydrolase) }\end{array}$ & $\begin{array}{c}\text { Peak II } \\
\text { (citrate synthase) }\end{array}$ \\
\hline $\begin{array}{l}\text { Pseudomonas AMI } \\
\text { wild-type }\end{array}$ & $\begin{array}{l}\text { Succinate } \\
\text { Hydroxybutyrate }\end{array}$ & $\begin{array}{l}8 \cdot 3 \\
9 \cdot 8\end{array}$ & $7 \cdot 0$ & $213(190)^{*}$ \\
\hline ICT5 I & $\begin{array}{l}\text { Succinate } \\
\text { Methanol }\end{array}$ & $\begin{array}{l}220 \\
250\end{array}$ & 210 & 154 \\
\hline ICT5IR & $\begin{array}{l}\text { Succinate } \\
\text { Hydroxybutyrate }\end{array}$ & $\begin{array}{l}220 \\
290\end{array}$ & 200 & 133 \\
\hline $\begin{array}{l}\text { ICT5IRaI } \\
\text { ICT5IRa2 } \\
\text { ICT5IRbI } \\
\text { ICT5IRb2 }\end{array}$ & $\begin{array}{l}\text { Hydroxybutyrate } \\
\text { Hydroxybutyrate } \\
\text { Hydroxybutyrate } \\
\text { Hydroxybutyrate }\end{array}$ & $\begin{array}{l}140 \\
10.0 \\
10.5 \\
90\end{array}$ & & \\
\hline ICT5IRCI & Hydroxybutyrate & $7 \cdot 9$ & $7 \cdot I$ & 96 \\
\hline
\end{tabular}

* This value was determined using citrate synthase purified further on Sephadex G-200 (see text).

coincidence of this secondary peak of hydrolase activity with the citrate synthase peak suggested that the latter enzyme might also be contributing to the observed hydrolysis of malyl-CoA. The hydrolase activity in pool II was much increased when higher concentrations of malyl-CoA were used in the assay. A determination of the $K_{\mathrm{m}}$ values for malyl-CoA, hydrolysed by the enzymes present in pool I and pool II, showed that the $K_{\mathrm{m}}$ value for the hydrolase in pool I was much lower than that in pool II (Table 2). (The $K_{\mathrm{m}}$ value for the hydrolase activity of a more purified citrate synthase preparation was also determined, see below.) When equal volumes of pools I and II were mixed and assayed for malate synthase activity using either the standard or the modified assay (see Methods), a high apparent malate synthase activity was observed; the specific activity of the latter was similar to the observed specific activity of the malyl-CoA hydrolase in pool I.

\section{Chromatography of pools I and II on Sephadex G-200: molecular weight determination}

A portion ( $\mathrm{I} \mathrm{ml}$ ) of the concentrated pool I preparation containing $2 \cdot 3$ units of malylCoA hydrolase was mixed with $0.5 \mathrm{ml}$ of the concentrated pool II preparation containing 4.3 units of malyl-CoA lyase. To this mixture, the following proteins were added as molecular-weight markers: $1 \cdot 3 \mathrm{mg}$ apoferritin, mol. wt 480000 (Harrison, 1963); 100 units of catalase, mol. wt 240000 (Samejima \& Yang, 1963); 55 units of lactate dehydrogenase, mol. wt 132000 (Fromm, 1963); 3 mg of cytochrome $c$, mol. wt I 2400 (Margoliash, 1962). The complete mixture was applied to a Sephadex G-200 column $(90 \times 2.5 \mathrm{~cm})$ equilibrated at $4{ }^{\circ} \mathrm{C}$ with $0.02 \mathrm{M}$-Tris- $\mathrm{HCl}$ buffer, $\mathrm{pH} 8.0$, containing $0.0 \mathrm{I} \mathrm{M}-\mathrm{MgCl}_{2}$. The column was eluted with the buffer used for equilibration and fractions $(2.4 \mathrm{ml})$ were collected and assayed for malyl-CoA hydrolase and malyl-CoA lyase activities. Marker enzyme activities were assayed by the methods used by Andrews (1965). Apoferritin and cytochrome $c$ were 


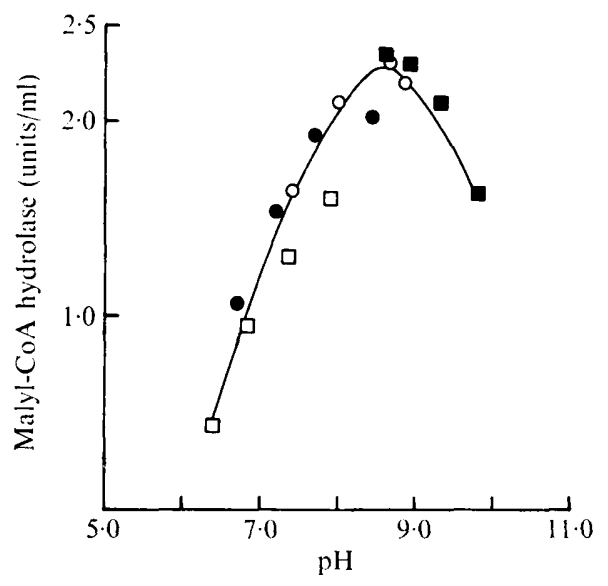

Fig. 2. pH-dependence of malyl-CoA hydrolase. Activities were measured in $0.1 \mathrm{M}-\mathrm{Tris}-\mathrm{HCl}(\mathrm{O})$, $0 . \mathrm{I}$ M-triethanolamine hydrochloride- $\mathrm{NaOH}(\mathrm{O})$, O.I M- $\mathrm{KH}_{2} \mathrm{PO}_{4}-\mathrm{KOH}(\square)$ and $\mathrm{O} \cdot \mathrm{I}$ M-diethanolamine-HCl ( $\square$ ) buffers. Reaction mixtures (I ml) contained: $100 \mu$ mol buffer; $50 \mu \mathrm{mol} \mathrm{MgCl}_{2}$; $0.2 \mu \mathrm{mol} \mathrm{DTNB}$; and $0.04 \mu \mathrm{mol}$ of malyl-CoA. Malyl-CoA hydrolase (pool I concentrate, 23 m units) prepared from succinate-grown Pseudomonas AMI was added to start the reaction and rate of hydrolysis at $30^{\circ} \mathrm{C}$ was followed at $4 \mathrm{I} 2 \mathrm{~nm}$.

detected by measurement of $E_{230}$ and $E_{412}$ respectively. Molecular weight values for malyl$\mathrm{CoA}$ hydrolase and malyl-CoA lyase of 190000 and 220000 respectively were calculated using the method of Andrews (I965). The molecular weight of malyl-CoA lyase has been determined as 190000 by Hacking \& Quayle (1974) using sedimentation equilibrium data for the purified enzyme. Citrate synthase activity was not detected in these fractions and a second experiment was performed in which $0.5 \mathrm{ml}$ of the concentrated pool II preparation, containing 3.9 units of citrate synthase, was mixed with marker proteins and applied to a Sephadex G-200 column $(66 \times 2.6 \mathrm{~cm})$ equilibrated at $4{ }^{\circ} \mathrm{C}$ with $0.02 \mathrm{M}$-Tris- $\mathrm{HCl}$ buffer, pH $8 \cdot 0$, containing $0 \cdot \mathrm{I} \mathrm{M}-\mathrm{KCl}$ and I mM-EDTA (Weitzman, I969). The column was eluted with this buffer and fractions $(2.4 \mathrm{ml})$ collected. A total of 1.8 units of citrate synthase was recovered and a value of 300000 was calculated for the molecular weight of this enzyme. Fraction 47 which contained a total of 80 munits of citrate synthase and 19 munits of malyl-CoA lyase was used to determine the $K_{\mathrm{m}}$ for malyl-CoA in the malyl-CoA hydrolase activity of citrate synthase (Table 2 ).

\section{Properties of malyl-CoA hydrolase}

The following properties of the malyl-CoA hydrolase (pool I concentrate) prepared from succinate-grown Pseudomonas AMI were examined. This preparation contained 0.40 units of malyl-CoA hydrolase per $\mathrm{mg}$ protein which represented about a Io-fold purification from the crude extract (Table I).

Stability. A $50 \%$ loss in specific activity was observed in a portion of the enzyme preparation stored for 3 months at $-15{ }^{\circ} \mathrm{C}$. Loss of activity was accelerated by repeated cycles of freezing and thawing.

$\mathrm{pH}$ optimum. The activity of malyl-CoA hydrolase was investigated as a function of $\mathrm{pH}$ over the range $6 \cdot 4$ to $9 \cdot 8$. The hydrolase was found to have a broad $\mathrm{pH}$ optimum with the peak of activity at $\mathrm{pH} 8.6$ (Fig. 2).

Metal-ion requirement. Malyl-CoA hydrolase activity was increased by approx. $60 \%$ in the presence of $5 \mathrm{mM}-\mathrm{MgCl}_{2} ; 10 \mathrm{mM}-\mathrm{MgCl}_{2}$ did not stimulate activity any further. No 


\section{Table 3. Substrate specificity of malyl-CoA hydrolase}

Reaction mixtures $\left(\mathrm{I} \mathrm{ml}\right.$ ) contained: $100 \mu \mathrm{mol}$ Tris- $\mathrm{HCl}$ buffer, $\mathrm{pH} 8.0 ; 50 \mu \mathrm{mol} \mathrm{MgCl}_{2} ; 0.2 \mu \mathrm{mol}$ DTNB; and one of a range of concentrations of the thiol-ester substrates. Malyl-CoA hydrolase (pool I concentrate, 14 munits) prepared from succinate-grown Pseudomonas AMI was added to start the reaction and the rate of hydrolysis at $30^{\circ} \mathrm{C}$ was followed at $4 \mathrm{I} 2 \mathrm{~nm} . K_{\mathrm{m}}$ and $V_{\max }$ values for acetyl-CoA refer to the initial rate of hydrolysis (see text).

Substrate
$(2 S)-4-M a l y l-C o A^{*}$
$(2 R)-4-M a l y l-C o A$
Succinyl-CoA
$(R S)-3-H y d r o x y b u t y r y l-C o A$
Acetyl-CoA

\begin{tabular}{cr}
$K_{\mathrm{m}}(\mu \mathrm{M})$ & \multicolumn{2}{c}{$V_{\max }$ relative to } \\
7.0 & malyl-CoA $(\%)$ \\
not hydrolysed & 100 \\
$7 \mathrm{I}$ & 194 \\
190 & 48 \\
1100 & 143
\end{tabular}

* At malyl-CoA concentrations higher than $40 \mu \mathrm{M}$, substrate inhibition of hydrolysis was observed.

absolute requirement for $\mathrm{Mg}^{2+}$ was found, even in enzyme which was dialysed for $2 \mathrm{~h}$ at $4{ }^{\circ} \mathrm{C}$ against 2500 vols. of $0.02 \mathrm{M}-\mathrm{KH}_{2} \mathrm{PO}_{4}-\mathrm{KOH}$ buffer, $\mathrm{pH} 7 \cdot 0$. The malyl-CoA hydrolase activity of citrate synthase (fraction 47, purified from pool II by Sephadex G-200 chromatography), was not stimulated by $5 \mathrm{~mm}-\mathrm{MgCl}_{2}$.

Substrate specificity. Malyl-CoA hydrolase completely hydrolysed (2S)-4-malyl-CoA. Some activity was observed when $0.2 \mu \mathrm{mol}$ of $(2 R)-4$-malyl-CoA was substituted for $(2 S)$ 4 -malyl-CoA in the standard reaction mixture, but the activity was low and the total substrate hydrolysed corresponded to only about $10 \%$ of the substrate supplied (as estimated by alkaline hydrolysis of the thioester bond). This observation was similar to that made by Hacking \& Quayle (1974) when examining the cleavage of a sample of the same batch of $(2 R)$-4-malyl-CoA by malyl-CoA lyase, and is probably due to contamination of the $2 R$ isomer by the $2 S$ substrate. The inhibition of hydrolysis of $(2 S)-4-$ malyl-CoA by the $2 R$ isomer was competitive with a value of $76 \mu \mathrm{M}$ for the $K_{\mathrm{i}}$ of $(2 R)-4-\mathrm{malyl}-\mathrm{CoA}$.

Succinyl-CoA and $(R S)$-3-hydroxybutyryl-CoA were hydrolysed by the enzyme with $K_{\mathrm{m}}$ values higher than the $K_{\mathrm{m}}$ with respect to malyl-CoA (Table 3). When acetyl-CoA was substituted for malyl-CoA, a rapid rate of hydrolysis was observed for a few seconds but this decreased to a very slow rate when only $5 \%$ of the substrate had been hydrolysed. Further additions of acetyl-CoA did not increase this slow rate of hydrolysis significantly (although higher initial rates were observed with higher concentrations of acetyl-CoA).

The effect of acetyl-CoA on the hydrolysis of $(2 S)-4$-malyl-CoA was investigated. The standard reaction mixture ( $\mathrm{I} \mathrm{ml}$ ) contained 4.5 m units enzyme and $0.068 \mu \mathrm{mol}$ acetyl-CoA. After $5 \mathrm{~min}$, when the initial rapid rate of hydrolysis had slowed, malyl-CoA $(0.04 \mu \mathrm{mol})$ was added and the rate of hydrolysis recorded. This was repeated using a range of malylCoA concentrations. Increasing concentrations of acetyl-CoA caused a progressive decrease in the rate of hydrolysis of malyl-CoA, $50 \%$ inhibition occurring with approx. $0.2 \mathrm{~mm}-$ acetyl-CoA. A double reciprocal plot of the data showed that the inhibition by acetyl-CoA was non-competitive and that the $K_{\mathrm{m}}$ for malyl-CoA was not significantly changed in the presence of acetyl-CoA. The nature of the inhibition by acetyl-CoA of its own hydrolysis and that of malyl-CoA was not further investigated.

\section{Chromatography of the crude extract of mutant ICT5 I on DEAE-cellulose}

ICT5I, a mutant of Pseudomonas AMI unable to grow on ethanol, malonate or 3-hydroxybutyrate, and lacking any apparent malate synthase activity (Taylor \& Anthony, 1975), was grown in liquid succinate medium and a crude extract prepared as described in Methods. 


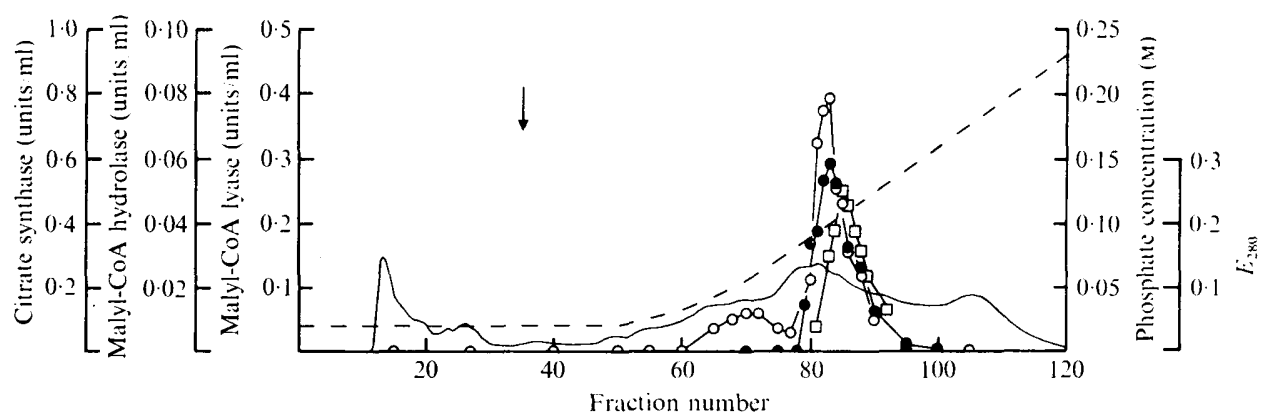

Fig. 3. DEAE-cellulose chromatography of crude extract of succinate-grown mutant ICT5I. MalylCoA hydrolase $(O)$ was assayed with $80 \mu \mathrm{M}$-malyl-CoA, and malyl-CoA lyase ( $\square$ ) with $40 \mu \mathrm{M}$ malyl-CoA. Citrate synthase $(O)$ was assayed as described in Methods.,$- E_{280}$ of the column eluate, measured with a Uvicord u.v. monitor (light path $3 \mathrm{~mm}$ ). - - -, Phosphate concentration; the arrow shows where the phosphate gradient was started.

\section{Table 4. Growth substrate specificity of Pseudomonas AMI and mutants}

Growth was tested by streaking each organism on agar plates containing potential growth substrates at a concentration of $0.2 \%$, except for the mixture of acetate and glyoxylate which were at $20 \mathrm{~mm}$ and $5 \mathrm{~mm}$ respectively. Growth was compared to the wild-type organism and to the growth of each strain on an agar plate containing no added growth substrate, after incubation at $30{ }^{\circ} \mathrm{C}$ for 3 to 4 days and 7 to 10 days.

\begin{tabular}{|c|c|c|c|c|c|c|c|c|}
\hline Substrate & $\begin{array}{c}P s . \text { AM I } \\
\text { wild- } \\
\text { type }\end{array}$ & ICT5 I & $\begin{array}{l}\text { ICT5I } \\
a, b, c\end{array}$ & ICT5IR & $\begin{array}{c}\text { ICT5 I R } \\
\text { a I }\end{array}$ & $\begin{array}{l}\text { ICT5I } \\
\text { a2, b1, } \\
\text { b2, cI }\end{array}$ & РCT57 & PCT57R4 \\
\hline Methanol & ++ & ++ & ++ & ++ & ++ & ++ & - & ++ \\
\hline Ethanol & ++ & - & - & ++ & ++ & ++ & ++ & ++ \\
\hline Acetate + glyoxylate & + & - & - & + & - & + & \pm & - \\
\hline Hydroxybutyrate & ++ & \pm & \pm & ++ & ++ & ++ & ++ & ++ \\
\hline Malonate & ++ & \pm & \pm & ++ & ++ & ++ & ++ & ++ \\
\hline Lactate & ++ & ++ & ++ & ++ & ++ & ++ & ++ & ++ \\
\hline Pyruvate & ++ & ++ & ++ & ++ & ++ & ++ & ++ & ++ \\
\hline Succinate & ++ & ++ & ++ & ++ & ++ & ++ & ++ & ++ \\
\hline Succinate + & - & - & ++ & ++ & ++ & ++ & - & ++ \\
\hline
\end{tabular}

(I $\left.\mathrm{mg} \mathrm{m}^{-1}\right)$

++ , Good growth after 3 to 4 days incubation; + , good growth after 7 to Io days incubation; \pm , slight growth after 7 to Io days incubation; -, no significant growth after 7 to ro days incubation.

The extract (39 $\mathrm{mg}$ protein $\mathrm{ml}^{-1}$ ) was assayed for malyl-CoA hydrolase, malyl-CoA lyase, malate synthase and citrate synthase (Table $\mathrm{I}$ ); and then, after protamine sulphate treatment, the supernatant (I $44 \mathrm{mg}$ protein : $6 \mathrm{ml}$ ) was fractionated on a DEAE-cellulose column, in the same way as described for the extract from the wild-type organism (Fig. 3). In this experiment malyl-CoA hydrolase was assayed in fractions using a higher concentration $(80 \mu \mathrm{M})$ of malyl-CoA in the standard reaction mixture; this accounts for the higher activity of the second hydrolase peak (citrate synthase) in Fig. 3 compared with that shown in Fig. I.

$K_{\mathrm{m}}$ values for both peaks of hydrolase activity were determined (Table 2). The $K_{\mathrm{m}}$ value with respect to malyl-CoA for the citrate synthase in ICT5I was about $70 \%$ of the value determined for the citrate synthase from the wild-type organism; but the malyl-CoA hydrolase of ICT5I had a $K_{\mathrm{m}}$ value for malyl-CoA about 30 times higher than that for the wild-type. The total activity recovered from ICT5I was only $5 \%$ of that recovered from the same quantity of wild-type organism. This comparison is based on activity measured using the standard assay system for both ICT5I and wild-type, i.e. using $40 \mu \mathrm{M}$ malyl-CoA in the 
reaction mixture. Fractions 80 to 9I (Fig. 3), which were comparable with pool II from the wild-type organism, contained a total of 15.9 units of citrate synthase and II 7 units of malyl-CoA lyase activity (approx. $65 \%$ and $43 \%$ respectively of the activities of these enzymes present in pool II).

\section{Revertants of mutant $\mathrm{ICT} 5 \mathrm{I}$}

Taylor \& Anthony (1976) have prepared a revertant of ICT5I, named ICT5IR, which can grow on a mixture of acetate $(20 \mathrm{~mm})$ and glyoxylate $(5 \mathrm{~mm})$. This revertant also regained the ability to grow on ethanol, malonate and 3-hydroxybutyrate (Table 4). However, Taylor \& Anthony were unable to detect any apparent malate synthase activity in crude extracts of ICT5IR. The malyl-CoA hydrolase activity found in extracts of ICT5IR was similar to that found in ICT5I (Table 2) and the $K_{\mathrm{m}}$ for malyl-CoA hydrolysis in such extracts was high $(220 \mu \mathrm{M})$. Accordingly other revertants of ICT5I (to growth on 3-hydroxybutyrate) were prepared (see Methods) and crude extracts examined for malyl-CoA hydrolase to determine whether or not revertants similar to the wild-type organism could be isolated. Two classes of revertant were found: (i) those similar to ICT5IR, i.e. having low malyl-CoA lyase activity in crude extracts and a high $K_{\mathrm{m}}$ for malyl-CoA and (ii) those similar to the wild-type organism, i.e. having high malyl-CoA hydrolase activity and a low $K_{\mathrm{m}}$ for malyl-CoA (Table 2). The growth substrate specificities of five of these revertants, ICT5IRa I, a2, bI, b2 and cI are included in Table 4. ICT5IRa2, bI and $\mathrm{cI}_{\mathrm{I}}$ have a low $K_{\mathrm{m}}$ for malyl-CoA hydrolysis; ICT5IRa I and $\mathrm{b}_{2}$ are similar to ICT5IR in having a high $K_{\mathrm{m}}$.

\section{Chromatography of crude extracts of ICT5IR and ICT5IRcI on DEAE-cellulose}

ICT5IR and ICT5IRCI were each grown in liquid 3-hydroxybutyrate medium and crude extracts fractionated on DEAE-cellulose columns as described for the fractionation of crude extracts of Pseudomonas AMI and ICT5I. With ICT5IR, malyl-CoA lyase, citrate synthase and malyl-CoA hydrolase were eluted at the same phosphate concentrations and at similar activities to those at which these enzymes were eluted in the experiments with ICT5I (Fig. 3). With ICT5IRCI, the results were very similar to those obtained for the chromatography of crude extract of the wild-type organism (Fig. I).

\section{DISCUSSION}

Our results show that the 'malate synthase' activity observed in extracts of Pseudomonas AMI can be explained in terms of the concerted action of malyl-CoA lyase and a novel malyl-CoA hydrolase, as indicated in equations I to 3 (see Introduction). No evidence could be found for a discrete malate synthase enzyme. Citrate synthase (from pig heart) is known to hydrolyse (2S)-4-malyl-CoA (Eggerer et al., 1964) and the present work has shown that citrate synthase from Pseudomonas AMI can do likewise. It might therefore be argued that citrate synthase is responsible for reaction 2 in the overall sequence (equations I to 3 ). The kinetic characteristics of the enzymes make this unlikely since the $K_{\mathrm{m}}$ value for malylCoA hydrolysed by citrate synthase is approximately 20 times higher than the $K_{\mathrm{n}}$ for malyl-CoA hydrolysed by the new hydrolase. Furthermore, the 30 -fold increase in $K_{\mathrm{m}}$ for malyl-CoA hydrolase in mutant ICT5 I results in the loss of significant malate synthase activity in crude extracts, despite the presence of wild-type levels of citrate synthase and malyl-CoA lyase. It therefore seems clear that the affinity of citrate synthase for malyl-CoA is too low to effect significant coupling in the reaction sequence (equations I to 3 ) in crude extracts. Further confirmation of the postulate that malate synthase activity is represented by the sum of equations $I$ and 2 is given by mutant PCT57. This mutant lacks malyl-CoA lyase (Salem 
et al., 1974) and has no apparent malate synthase activity (Table I). Restoration of malylCoA lyase activity in revertant PCT57R4 results in restoration of malate synthase activity.

The evidence from mutants indicates that the reaction sequence (equations I to 3 ), probably functioning as a malate synthase, is involved in the metabolism of ethanol, malonate and 3-hydroxybutyrate by Pseudomonas AMI. Thus, ICT5I possesses an altered malyl-CoA hydrolase and is unable to grow on these substrates, while some revertants with wild-type malyl-CoA hydrolase activity regain the ability to grow on them. The isolation of other revertants of ICT5I which are able to grow on ethanol, malonate or 3-hydroxybutyrate but which still have the mutant (high $K_{\mathrm{m}}$ ) hydrolase indicates that an alternative to the malate synthase pathway can exist or be brought into play by further mutation. This is not unexpected since such a pathway, not involving an overall malate synthase reaction, must exist to allow for the growth of mutant PCT57 on these substrates, despite its lack of malate synthase activity. Salem et al. (I973c) proposed that the metabolism of lactate and pyruvate by Pseudomonas AM I differs fundamentally from that operating in the Enterobacteriaceae and that these substrates are catabolised to $C_{2}$ units from which $C_{4}$ compounds are formed via the malate synthase pathway. The observation that ICT5I can grow well on pyruvate or lactate although it has no apparent malate synthase activity (Taylor \& Anthony, 1975) indicates that although pyruvate and lactate may first be converted to $C_{2}$ units, an alternative pathway, not involving an overall malate synthase reaction, allows for the growth of ICT5I (and possibly the wild-type organism) on these substrates. This alternative pathway may well be the same as that used for growth on ethanol, malonate or 3-hydroxybutyrate by those revertants of ICT5I which still have the mutant (high $K_{\mathrm{m}}$ ) malyl-CoA hydrolase. The nature of this alternative pathway is not known.

The specific activity of malyl-CoA hydrolase remained fairly constant in Pseudomonas AMI grown on various substrates. Its presence in the $C_{1}$-grown organism calls for a regulatory mechanism to prevent hydrolysis of malyl-CoA before it is cleaved to acetyl-CoA and glyoxylate. It will be recalled that in the operation of the serine pathway during growth on $\mathrm{C}_{1}$ compounds, malyl-CoA lyase catalyses reaction ( $\mathrm{I}$ ) from right to left. The apparent inhibition of the hydrolase by acetyl-CoA suggests a possible means of regulation which may also prevent unwanted hydrolysis of acetyl-CoA itself.

Although a discrete malate synthase enzyme has not been found in Pseudomonas AMI, Cox (1974) has shown that such an enzyme is present in trimethylamine-grown bacterium $5 \mathrm{H} 2$. There is no obvious role for the enzyme during growth on $\mathrm{C}_{1}$-compounds by this organism which uses the isocitrate lyase-serine pathway. However, in contrast to Pseudomonas AMI, bacterium $5 \mathrm{H} 2$ is able to synthesize isocitrate lyase and thereby to grow on $\mathrm{C}_{2}-$ compounds by the glyoxylate cycle. Hence the presence of a malate synthase enzyme in this organism may perhaps be correlated with its ability to synthesize isocitrate lyase, bearing in mind that these two glyoxylate cycle enzymes are associated in an operon in Escherichia coli (Vanderwinkel \& de Vlieghere, I968). Further work is needed to establish whether or not such a correlation holds amongst $\mathrm{C}_{1}$-utilizing organisms in general.

It is interesting to speculate whether there could be an evolutionary link between malate synthase, and malyl-CoA lyase and hydrolase. Thus malate synthase might have evolved from a fusion of primitive malyl-CoA lyase and hydrolase enzymes, or the latter two enzymes might have evolved by separation of two peptide sequences from a parent malate synthase protein.

We thank Mr A. A. Hancock for skilled technical assistance and the Science Research Council for financial support under Grant no. B/RG/27I I 8 . 


\section{REFERENCES}

ANDrews, P. (1965). The gel-filtration behaviour of proteins related to their molecular weights over a wide range. Biochemical Journal 96, 595-606.

Anthony, C. (1975). The biochemistry of methylotrophic micro-organisms. Science Progress, Oxford 62, I67-206.

Cox, R. B. (1974). Aspects of the intermediary metabolism of the facultative methylotrophs bacterium $5 \mathrm{H} 2$ and bacterium 2B2. Ph.D. Thesis, University of Reading.

Cox, R. B. \& ZATMAN, L. J. (1973). Isocitrate lyase and adenosine triphosphate malate lyase as key enzymes for the methylotrophic growth of bacterium 5H2. Biochemical Society Transactions $\mathbf{1}, 669-671$.

DECKER, K. (1 963). L-(+)- $\beta$-Hydroxybutyryl Coenzyme A. In Methods of Enzymatic Analysis, pp. 44I-444. Edited by H.-U. Bergmeyer. New York and London: Academic.

Dixon, G. H. \& Kornberg, H. L. (1962). Malate synthetase from baker's yeast. In Methods in Enzymology, vol. 5, pp. 633-637. Edited by S. P. Colowick and N. O. Kaplan. New York: Academic.

Dunstan, P. M. \& Anthony, C. (1973). Microbial metabolism of $C_{1}$ and $C_{2}$ compounds. The role of acetate during growth of Pseudomonas AMI on $\mathrm{C}_{1}$ compounds, ethanol and $\beta$-hydroxybutyrate. Biochemical Journal 132, 797-80I.

Dunstan, P. M., Anthony, C. \& Drabble, W. T. (1972). Microbial metabolism of $\mathrm{C}_{1}$ and $\mathrm{C}_{2}$ compounds. The involvement of glycollate in the metabolism of ethanol and of acetate by Pseudomonas AMI. Biochemical Journal 128, 99-106.

EgGerer, H., Remberger, U. \& Grünewälder, C. (1964). Zum Mechanismus der biologischen Umwandlung von Citronensäure 5. Citrat-synthase, eine Hydrolase für Malyl-coenzyme A. Biochemische Zeitschrift 339, 436-453.

Fromm, H. J. (1963). Determination of dissociation constants of coenzymes and abortive ternary complexes with rabbit muscle lactate dehydrogenase from fluorescence measurements. Journal of Biological Chemistry 238, 2938-2944.

Hacking, A. J. \& Quayle, J. R. (I974). Purification and properties of malyl-coenzyme A lyase from Pseudomonas AMI. Biochemical Journal r39, 399-405.

Hampton, D. \& Zatman, L. J. (1973). The metabolism of tetramethylammonium chloride by bacterium 5H2. Biochemical Society Transactions I, 667-668.

HarRison, P. M. (1963). The structure of apoferritin: molecular size, shape and symmetry from X-ray data. Journal of Molecular Biology 6, 404-422.

JAYASURIYA, G. C. N. (1955). The isolation and characteristics of an oxalate-decomposing organism. Journal of General Microbiology 12, 419-428.

Kennedy, S. I. T. \& Fewson, C. A. (I968). Enzymes of the mandelate pathway in bacterium NCIB8250. Biochemical Journal ro7, 497-506.

Kornberg, H. L. (1959). Aspects of terminal respiration in micro-organisms. Annual Review of Microbiology I3, 49-78.

LARge, P. J. \& Quayle, J. R. (1963). Microbial growth on $\mathrm{C}_{1}$ compounds. 5. Enzyme activities in extracts of Pseudomonas AMI. Biochemical Journal 87, 386-396.

Leloir, L. F. \& Cardini, C. E. (1957). Characterization of phosphorous compounds by acid lability. In Methods in Enzymology, vol. 3, pp. 840-850. Edited by S. P. Colowick and N. O. Kaplan. New York: Academic.

LiNEWEAVER, H. \& BURK, D. (1934). The determination of enzyme dissociation constants. Journal of the American Chemical Society 56, 658-666.

Margoliash, E. (I962). Amino acid sequence of chymotryptic peptides from horse heart cytochrome $c$. Journal of Biological Chemistry 237, 2 I 6I-2 I 74.

Salem, A. R., Hacking, A. J. \& QuAYle, J. R. (1973a). Cleavage of malyl-CoA into acetyl-CoA and glyoxylate by Pseudomonas AMI. Journal of General Microbiology 77, xii.

Salem, A. R., Hacking, A. J. \& QuAYle, J. R. (1973 $b$ ). Cleavage of malyl-coenzyme A into acetyl-coenzyme A and glyoxylate by Pseudomonas AMI and other $C_{1}$-unit-utilizing bacteria. Biochemical Journal $\mathbf{1 3 6}^{2}$ $89-96$.

Salem, A. R., Wagner, C., Hacking, A. J. \& Quayle, J. R. (1973c). The metabolism of lactate and pyruvate by Pseudomonas AMi. Journal of General Microbiology 76, 375-388.

Salem, A. R., HACKIng, A. J. \& QuAYle, J. R. (1974). Lack of malyl-CoA lyase in a mutant of Pseudomonas AMI. Journal of General Microbiology 8I, 525-527.

SAMEJima, T. \& YANG, J. T. (1963). Reconstitution of acid-denatured catalase. Journal of Biological Chemistry 238, 3256-326I.

Srere, P. A. (1969). Citrate synthase. In Methods in Enzymology, vol. I3, pp. 3-1 I. Edited by J. M. Lowenstein. New York and London: Academic.

TAYLOR, I. J. \& ANTHONY, C. (1975). Microbial metabolism of $\mathrm{C}_{1}$ and $\mathrm{C}_{2}$ compounds: mutants of Pseudomonas AM I lacking malate synthase and acetyl-CoA synthetase. Proceedings of the Society for General Microbiology 2, 52-53. 
TAYLOR, 1. J. \& ANTHONY, C. (1976). Acetyl-CoA production and utilization during growth of the facultative methylotroph Pseudomonas AMI on ethanol, malonate and 3-hydroxybutyrate. Journal of General Microbiology 95, I 34-I43.

TubBs, P. K. \& Garland, P. B. (1969). Assay of coenzyme A and some acyl derivatives. In Methods in Enzymology, vol. 13, pp. 535-55I. Edited by J. M. Lowenstein. New York and London: Academic.

VANDERWINKel, E. \& DE VLIEGHERE, M. (I968). Physiologie et genetique de l'isocitratase et des malate synthetases chez Escherichia coli. European Journal of Biochemistry 5, 8I-90.

Weitzman, P. D. J. (1969). Citrate synthase from Escherichia coli. In Methods in Enzymology, vol. I3, pp. 22-26. Edited by J. M. Lowenstein. New York and London: Academic. 